\title{
THE REACTION OF RATS TO DIETS CONTAINING OCTAMETHYL PYROPHOSPHORAMIDE (SCHRADAN) AND OO-DIETHYL-S-ETHYLMERCAPTOETHANOL THIOPHOSPHATE ("SYSTOX")
}

BY

\author{
J. M. BARNES and F. A. DENZ \\ From the Toxicology Research Unit, Serum Research Institute, Carshalton Beeches, Surrey
}

(RECEIVED FOR PUBLICATION AUGUST 4, 1953)

The compounds octamethyl pyrophosphoramide (schradan) and OO diethyl S. ethylmercaptoethanol-thiophosphate (" systox"*) are the active ingredients of certain insecticide preparations. Because they are actually taken up by the plants to which they are applied they have been termed "systemic" insecticides. The presence of these insecticides is responsible for the death of the insects feeding on the plants, and also poses a problem in assessing any toxic hazard that may arise from the consumption of the same plants or parts of them at a later stage by man.

Previous work with OO - diethyl O-p-nitrophenyl thiophosphate (E605, parathion) by Barnes and Denz (1951) has shown that rats which had received a diet containing 20 p.p.m. parathion for one year were apparently normal by the conventional standards of toxicity tests such as behaviour, rate of growth, mortality, and pathological changes in the tissues. Parathion inhibits the cholinesterase of animals to which it is administered, and Frawley, Hagen, and Fitzhugh (1952) observed a significant reduction of the cholinesterase activity of the blood and brain of rats receiving as little as 5 p.p.m. parathion in their food. The inhibition of cholinesterase is thus a more sensitive indicator of the absorption of parathion than the conventional tests for chronic toxicity.

In this paper both the general reaction and the specific effect upon cholinesterase in rats that had received several concentrations of schradan and "systox" in their diet are recorded. A number of differences in the reaction of the rats to the two compounds was observed and the findings also indicate the problem of assessing " chronic toxicity".

The formula of schradan is given in Fig. 1.
Pure schradan has very little activity as an inhibitor of cholinesterase in vitro. The material used in these experiments was a commercial preparation containing $65 \%$ of active ingredient. It also had a considerable activity and tested against rat brain and rat plasma cholinesterase in vitro it produced $50 \%$ inhibition at $8.5 \times 10^{-5} \mathrm{M}$.

DuBois, Doull, and Coon (1950) stated that the acute oral lethal dose of schradan was $9-10 \mathrm{mg}$. per $\mathrm{kg}$. for male and female rats.

The toxicity of the material used in these experiments was tested by oral administration of aqueous solutions. The average single lethal dose was 6.5 $\mathrm{mg}$. per kg. for male and $27.5 \mathrm{mg}$. per kg. for female rats. The dose is expressed in terms of the active ingredient.

DuBois and others (1950) found that the daily injection of $1 \mathrm{mg}$. per $\mathrm{kg}$. killed all rats within eight days but rats could tolerate a daily dose of $0.5 \mathrm{mg}$. per $\mathrm{kg}$. for at least four weeks.

Rider, Ellinwood, and Coon (1952) in a small series of rats found that a daily dose of $0.5 \mathrm{mg}$. per $\mathrm{kg}$. by injection raised the tolerance of rats so that they could then withstand a daily dose of 1.0 mg. per kg. which would otherwise have killed them.

"Systox" is known to be a mixture of isomers the formulae of which are given in Fig. 1 (Wirth, 1953 ; Gardiner and Heath, 1953). The material used in these experiments was analysed before the experiments were started and again some weeks after they had been concluded. On both occasions the samp.e was found to contain $48 \%$ of the $\mathrm{P}=\mathrm{O}$ isomer. Wirth (1953) found that the L.D.50 for male rats given a single oral dose was $7.5 \mathrm{mg}$. per $\mathrm{kg}$. for the $\mathbf{P}=\mathrm{S}$ isomer and $1.5 \mathrm{mg}$. per $\mathrm{kg}$. for the $\mathrm{P}=\mathrm{O}$ isomer.

The material used in these experiments had an 
approximate L.D.50 of $10 \mathrm{mg}$. per $\mathrm{kg}$. for male rats and $4 \mathrm{mg}$. per $\mathrm{kg}$. for female rats given orally as an alcoholic solution diluted 1 in 100 in water just before administration. The rats used in these experiments must have been less sensitive than those used by Wirth, for from his figures the L.D.50 for male rats should have been not greater than $3 \mathrm{mg}$. per $\mathrm{kg}$. on the basis of the $\mathbf{P}=\mathbf{O}$ isomer content alone.
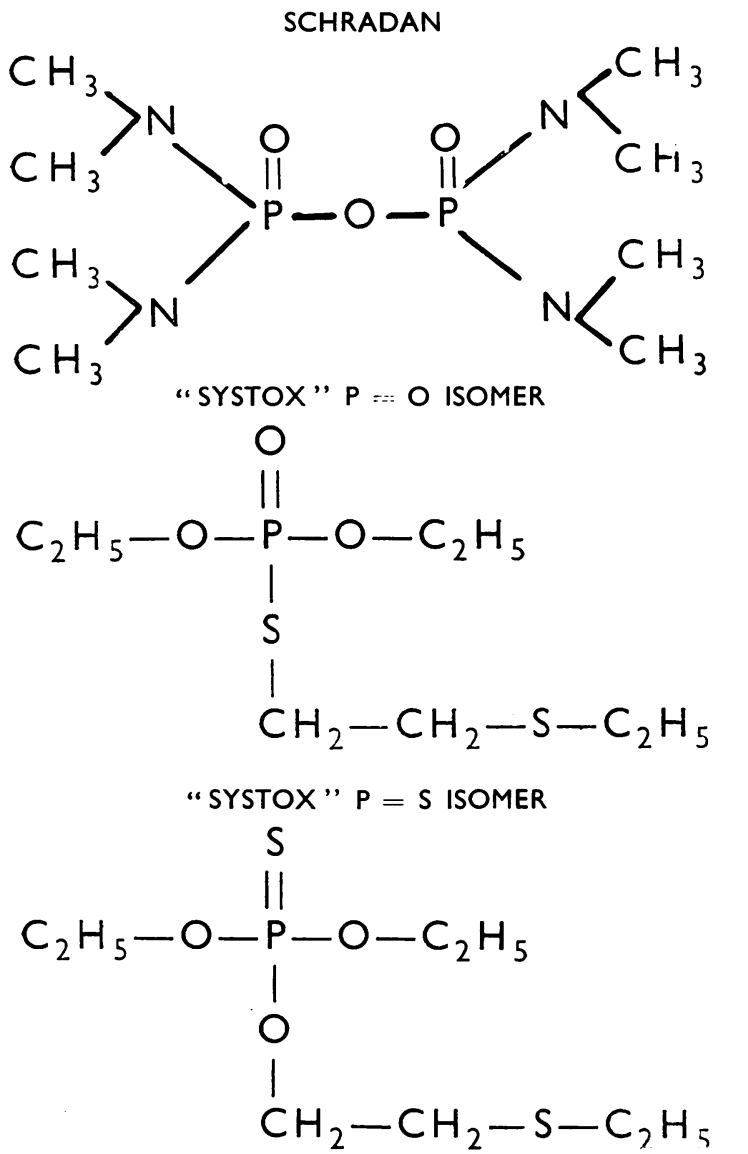

FIG. 1.-Formulae of schradan (octamethyl pyrophosphoramide) and the isomers of "systox" (0 0-diethyl ethyl mercaptoethanol thiophosphate).

The material used was tested against rat brain and rat plasma cholinesterase and produced a $50 \%$ inhibition in concentrations of $4 \times 10^{-6} \mathrm{M}$ and $2.4 \times 10^{-6} \mathrm{M}$ respectively.

\section{Materials and Methods}

Male and female albino rats from the same stock were used. They were individually marked but housed six to eight in a cage.
A stock diet (M.R.C. Diet 41) was available in a powder form but was fed to the rats as a stiff paste made by adding $70 \mathrm{ml}$. of water to each $100 \mathrm{~g}$. A weighed quantity was given daily to each cage. In the later experiments the food remaining next day was weighed so that the daily intake could be estimated.

The drugs were administered by adding them to water used to prepare the paste from the dry diets. Stock solutions were made up so that a fixed volume $(1 \mathrm{ml}$.) had to be added to each $100 \mathrm{~g}$. of diet in order to provide the required concentration. Schradan was available as a commercial preparation containing $65 \%$ active ingredient. Since it was stable, stock solutions were made up in water. "Systox" was available as the active ingredients of commercial preparations. Stock solutions were made in ethanol.

Animal weights were recorded once or twice a week.

All animals were killed by carbon monoxide. Tissues for histology were fixed in Helly's fluid and after processing were stained with haematoxylin and eosin.

Cholinesterase determinations were by the methods of Nachmansohn and Rothenberg (1945) with details given by Aldridge (1950). Acetylcholine was used as the substrate so that the activity measured was that due to both the true and pseudo cholinesterase. The predominant enzyme in the rat brain is true cholinesterase and the organ was removed whole, weighed, and homogenized in an all-glass homogenizer.

In the first experiments the activity of whole blood was determined. This measured the combincd activity of the true cholinesterase, which is present in the red cells only, and the pseudo-cholinesterase of the plasma. In later experiments these were determined separately. The personal error of the two technicians carrying out the determinations was also measured, and found to represent differences of 3 to $4 \%$ in the readings.

\section{Results}

Some details of the experiments that were carried out are given in Table 1 . The experiments are numbered and reference to this number is made in subsequent tables.

Schradan.-The male rats on 50 p.p.m. were the only ones to show signs of poisoning. These were not severe and consisted of slight general weakness and persistent, fine, muscular fasciculations. These signs disappeared within 12 weeks and were not seen again during the 52 weeks of the experiment. 
TABLE 1

FEEDING EXPERIMENTS CARRIED OUT WITH SCHRADAN AND "SYSTOX"

\begin{tabular}{|c|c|c|c|c|c|}
\hline \multirow[t]{2}{*}{ Compound } & \multirow{2}{*}{$\begin{array}{c}\text { Experi- } \\
\text { ment } \\
\text { No. }\end{array}$} & \multirow{2}{*}{$\begin{array}{c}\text { Duration } \\
\text { (weeks) }\end{array}$} & \multirow{2}{*}{$\begin{array}{c}\text { Concen- } \\
\text { tration } \\
\text { of Dose* } \\
\text { (p.p.m.) }\end{array}$} & \multicolumn{2}{|c|}{$\begin{array}{c}\text { Numbers of } \\
\text { Rats }\end{array}$} \\
\hline & & & & Male & Female \\
\hline \multirow[t]{3}{*}{ Schradan $\quad}$. & $\frac{1}{-}$ & $\frac{52}{-}$ & $\begin{array}{r}50 \\
10 \\
0\end{array}$ & $\begin{array}{l}8 \\
8 \\
8\end{array}$ & $\begin{array}{l}8 \\
8 \\
8\end{array}$ \\
\hline & $\frac{2}{-}$ & $\frac{13}{-}$ & $\begin{array}{r}10 \\
3 \\
1 \\
0\end{array}$ & $\begin{array}{l}12 \\
12 \\
12 \\
12\end{array}$ & E \\
\hline & $\frac{3}{-}$ & $\frac{4}{-}$ & $\begin{array}{l}1 \\
0 \cdot 3 \\
0 \cdot 1 \\
0\end{array}$ & $\begin{array}{l}12 \\
12 \\
12 \\
12\end{array}$ & E \\
\hline \multirow[t]{2}{*}{ "Systox" } & $\frac{4}{-}$ & $\frac{16}{-}$ & $\begin{array}{r}50 \\
20 \\
10 \\
0\end{array}$ & $\bar{z}$ & $\begin{array}{l}12 \\
12 \\
12 \\
12\end{array}$ \\
\hline & $\underline{5}$ & $\frac{11}{-}$ & $\begin{array}{r}10 \\
3 \\
1 \\
0\end{array}$ & E & $\begin{array}{l}18 \\
18 \\
18 \\
18\end{array}$ \\
\hline
\end{tabular}

*Dose is the amount of active ingredient added to the dry diet.

The rates of growth of the groups are given in Figs. 2 and 3. Only the male rats (Fig. 2) on 50 p.p.m. did not grow normally and they remained under weight for at least the first 18 weeks of the experiment (Table 2).

The significance of any difference between the weight of this group and the control animals was reduced in the later part of the experiment by the unusually wide scatter of weights in the control group.

During the year there were two deaths from unknown causes among the controls, and three rats from the 10 p.p.m. groups were killed because of middle-ear disease. There were no deaths among

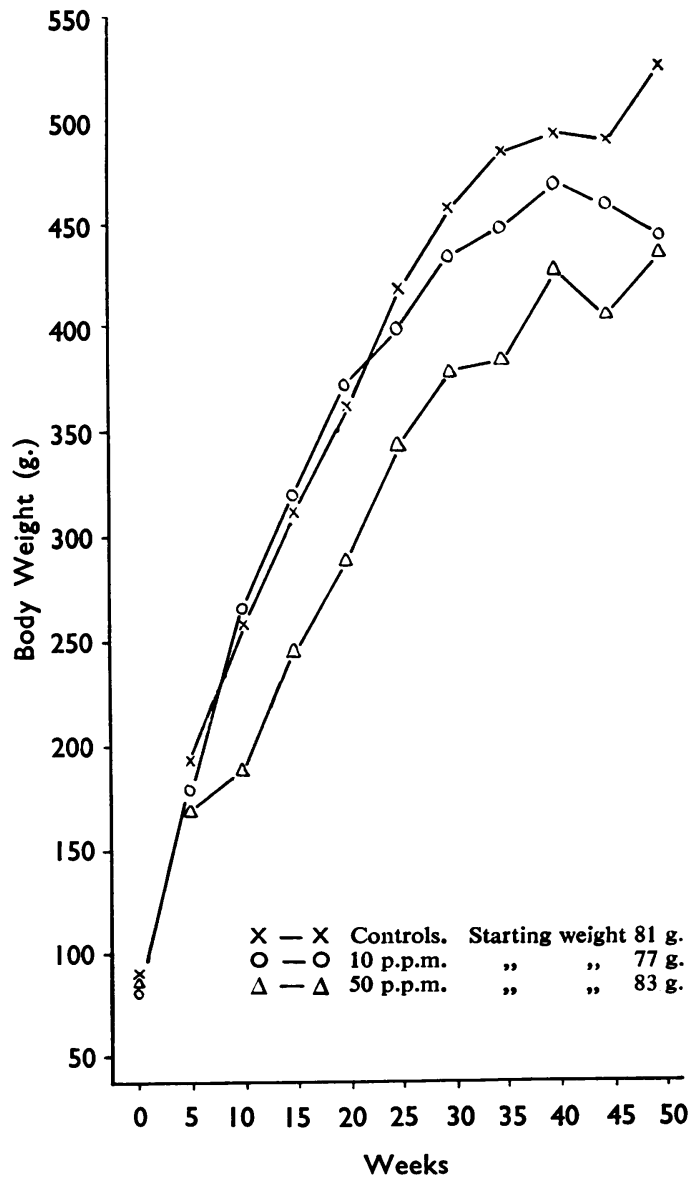

FIG. 2.-Weights of male rats on diets containing schradan (Experiment 1).

TABLE 2

COMPARISON BETWEEN MEAN WEIGHTS AND DAILY FOOD INTAKE OF MALE RATS ON 50 P.P.M. SCHRADAN AND CONTROLS

\begin{tabular}{|c|c|c|c|c|c|c|}
\hline \multirow{2}{*}{$\begin{array}{c}\text { Time } \\
\text { (weeks) }\end{array}$} & \multicolumn{2}{|c|}{ Food Intake* } & \multicolumn{2}{|c|}{ Mean Body Weight (g.) with Standard Error } & \multirow{2}{*}{$\mathbf{t}$} & \multirow{2}{*}{$\mathbf{p}$} \\
\hline & Control & 50 p.p.m. & Control & 50 p.p.m. & & \\
\hline 0 & 一 & - & 81 & 83 & 一 & 一 \\
\hline 2 & 一 & 一 & $126 \pm 10$ & $114 \pm 15$ & $1 \cdot 74$ & $>0 \cdot 1$ \\
\hline 7 & - & - & $250 \pm 25$ & $166 \pm 12 \cdot 5$ & $8 \cdot 04$ & $<0.01$ \\
\hline 12 & - & - & $296 \pm 37$ & $221 \pm 22$ & $3 \cdot 75$ & $<0.01$ \\
\hline 17 & $7 \cdot 15 \pm \cdot 26$ & $6 \cdot 9 \pm \cdot 06$ & $358 \pm 52$ & $288 \pm 29$ & $3 \cdot 1$ & $<0.01$ \\
\hline 26 & - & - & $431 \pm 86$ & $350 \pm 30$ & 0.56 & $>\cdot 1$ \\
\hline 50 & $4.68 \pm .09$ & $5 \cdot 6 \pm \cdot 02$ & $490 \pm 100$ & $456 \pm 36$ & 0.74 & $>\cdot 1$ \\
\hline
\end{tabular}

*Food intake is given as $\mathrm{g}$. per rat per $100 \mathrm{~g}$. body weight per day and is the mean of three successive weeks (Experiment 1 ). 


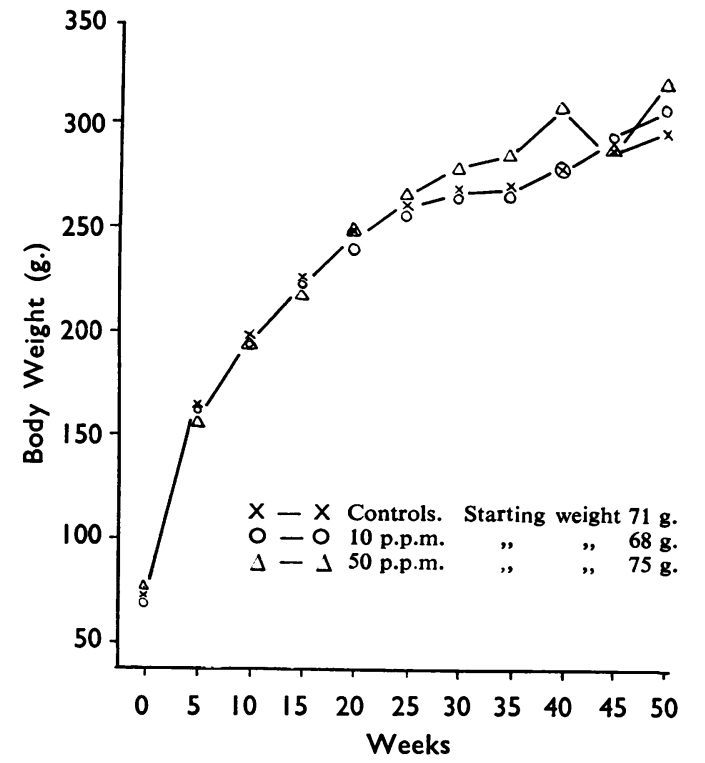

Fig. 3.-Weight of female rats on diets containing schradan (Experiment 1).

those on 50 p.p.m. but two were removed during the experiment for another purpose.

The food intake was not recorded until the sixteenth week of this experiment. The figures obtained during the sixteenth to eighteenth weeks show that the underweight males on 50 p.p.m. were eating a quantity per $100 \mathrm{~g}$. body weight similar to that eaten by the controls (Table 2). The daily dose of schradan consumed by these rats was equivalent to $3.45 \mathrm{mg}$. per $\mathrm{kg}$. per day or about half the single lethal dose.

The liver, kidney, and spleen of the rats were examined histologically. Special attention was paid to the liver because it has been shown that it is in the liver of the rat that schradan is converted to an active inhibitor of cholinesterase (Cheng, 1951). No pathological changes attributable to the action of schradan could be detected.

The results of determinations of the blood and brain cholinesterase activities are given in Tables 3 and 4.

At neither 10 p.p.m. nor 50 p.p.m. was there a marked reduction in the activity of the brain cholinesterase, but at both levels of feeding that of the blood cholinesterase was reduced. In this experiment (Table 3 ) it will be seen that the activity of the blood cholinesterase in the normal females was greater than that of the normal males. This has been described by others (Levine and Suran, 1951). However, at equal levels of schradan in the diet an almost equal reduction in activity of the blood cholinesterase of the two sexes was produced. At the time these rats were killed and the determinations made the females were eating $6.5 \pm 0.38 \mathrm{~g}$. food per $100 \mathrm{~g}$. body weight per day which was $20 \%$ more than the males $(5 \cdot 4 \pm 0 \cdot 36)$.

Further experiments were done on male rats only in order to find out the lowest dose level of schradan that would produce a detectable depression of the blood cholinesterase activity, and for this, separate determinations of red cell and plasma cholinesterase were made in addition to those on whole blood. The figures for rats on diets containing $10,3,1$, 0.3 and 0.1 p.p.m. schradan are given in Table 4. Although some of these experiments only ran for four weeks this gave time for the cholinesterase inhibition to reach a steady level as shown by the similarity of the figures obtained in the two experiments where 1 p.p.m. was fed. The experiments were done with an interval of several months;

TABLE 3

CHOLINESTER ASE ACTIVITY OF BRAIN AND WHOLE BLOOD OF RATS RECEIVING 10 AND 50 P.P.M. SCHRADAN FOR ONE YEAR

\begin{tabular}{|c|c|c|c|c|c|c|c|c|c|}
\hline \multirow{2}{*}{$\begin{array}{l}\text { Experi- } \\
\text { ment } 1\end{array}$} & \multirow{2}{*}{$\underset{\text { (p.p.m.) }}{\text { Drug in Diet }}$} & \multicolumn{4}{|c|}{ Male } & \multicolumn{4}{|c|}{ Female } \\
\hline & & $\begin{array}{c}{ }^{*} \mathrm{ChE} \\
\text { Activity }\end{array}$ & S.E. & $\begin{array}{l}\text { No. of } \\
\text { Rats }\end{array}$ & $\uparrow \%$ Activity & $\underset{\text { Activity }}{\mathrm{ChE}}$ & S.E. & $\begin{array}{l}\text { No. of } \\
\text { Rats }\end{array}$ & $\%$ Activity \\
\hline \multirow[t]{3}{*}{ Brain } & 0 & $180 \cdot 6$ & $9 \cdot 27$ & 8 & 100 & $166 \cdot 3$ & $4 \cdot 75$ & 6 & 100 \\
\hline & 10 & $142 \cdot 6$ & 21.69 & 3 & 79 & 154.7 & 10.09 & 7 & $92 \cdot 6$ \\
\hline & 50 & $152 \cdot 8$ & $8 \cdot 18$ & 8 & 84 & 130.6 & 6.07 & 6 & $78 \cdot 5$ \\
\hline \multirow[t]{3}{*}{ Blood } & 0 & 20.03 & 1.06 & 8 & 100 & $44 \cdot 2$ & $4 \cdot 55$ & 3 & 100 \\
\hline & 10 & $10 \cdot 59$ & $1 \cdot 29$ & 3 & 52 & $25 \cdot 59$ & $2 \cdot 48$ & 7 & $57 \cdot 9$ \\
\hline & 50 & $4 \cdot 82$ & 0.75 & 8 & $23 \cdot 5$ & $15 \cdot 17$ & 2.04 & 6 & $34 \cdot 3$ \\
\hline
\end{tabular}

Acetylcholine was used as substrate by techniques of Nachmansohn and Rothenberg (1945) and Aldridge (1950). ${ }^{*} \mathrm{ChE}$ activity $=$ Mean $\mu \mathrm{l}$. $\mathrm{CO}_{2}$ evolved per minute per $\mathrm{g}$. brain or ml. of blood.

$\uparrow \%$ activity $=$ Activity expressed as percentage of control group. 
TABLE 4

CHOLINESTERASE ACTIVITY OF BRAIN, WHOLE BLOOD, PLASMA, AND RED CELLS OF MALE RATS FED SCHRADAN

\begin{tabular}{|c|c|c|c|c|c|c|c|c|c|c|c|c|c|}
\hline Experiment & $2^{*}$ & $\begin{array}{c}\text { Drug in } \\
\text { Diet } \\
\text { (p.p.m.) }\end{array}$ & $\begin{array}{c}+\mathrm{ChE} \\
\text { Activity }\end{array}$ & S.E. & $\begin{array}{l}\text { No. of } \\
\text { Rats }\end{array}$ & **Activity & Experiment & & $\begin{array}{c}\text { Drug in } \\
\text { Diet } \\
\text { (p.p.m.) }\end{array}$ & $\begin{array}{c}\text { ChE } \\
\text { Activity }\end{array}$ & S.E. & $\begin{array}{l}\text { No. of } \\
\text { Rats }\end{array}$ & $\begin{array}{c}\% \\
\text { Activity }\end{array}$ \\
\hline Brain .. & $\ldots$ & $\begin{array}{r}0 \\
10 \\
3 \\
1\end{array}$ & $\begin{array}{l}199.03 \\
162.26 \\
184.84 \\
188.9\end{array}$ & $\begin{array}{l}5.53 \\
6.75 \\
6.81 \\
5.45\end{array}$ & $\begin{array}{l}6 \\
6 \\
6 \\
6\end{array}$ & $\begin{array}{l}100 \\
81 \cdot 5 \\
93 \\
95\end{array}$ & Brain.. & $\cdots$ & $\begin{array}{l}0 \\
1 \\
0 \cdot 3 \\
0 \cdot 1\end{array}$ & $\begin{array}{l}194 \cdot 33 \\
191 \cdot 56 \\
205 \cdot 43 \\
198 \cdot 34\end{array}$ & $\begin{array}{l}4 \cdot 33 \\
2 \cdot 53 \\
5 \cdot 58 \\
5 \cdot 21\end{array}$ & $\begin{array}{l}12 \\
12 \\
12 \\
12\end{array}$ & $\begin{array}{l}100 \\
98 \cdot 5 \\
105 \cdot 7 \\
102\end{array}$ \\
\hline Whole blood & .. & $\begin{array}{r}0 \\
10 \\
3 \\
1\end{array}$ & $\begin{array}{r}18 \cdot 58 \\
6 \cdot 80 \\
10 \cdot 29 \\
14 \cdot 59\end{array}$ & $\begin{array}{l}1.17 \\
0.37 \\
1.06 \\
0.77\end{array}$ & $\begin{array}{l}6 \\
5 \\
6 \\
6\end{array}$ & $\begin{array}{c}100 \\
42.7 \\
57 \\
79.5\end{array}$ & \multicolumn{2}{|l|}{ Whole blood } & $\begin{array}{l}0 \\
1 \\
0 \cdot 3 \\
0 \cdot 1\end{array}$ & $\begin{array}{l}15 \cdot 39 \\
12.45 \\
15 \cdot 79 \\
15 \cdot 25\end{array}$ & $\begin{array}{l}0.39 \\
0.18 \\
0.21 \\
0.35\end{array}$ & $\begin{array}{l}12 \\
12 \\
12 \\
12\end{array}$ & $\begin{array}{c}100 \\
80.9 \\
102.5 \\
99.04\end{array}$ \\
\hline Plasma & . & $\begin{array}{r}0 \\
10 \\
3 \\
1\end{array}$ & $\begin{array}{r}11.27 \\
5.65 \\
8.57 \\
10.87\end{array}$ & $\begin{array}{l}0.94 \\
0.22 \\
1.25 \\
0.71\end{array}$ & $\begin{array}{l}6 \\
5 \\
6 \\
6\end{array}$ & $\begin{array}{c}100 \\
49.7 \\
76 \\
96.4\end{array}$ & Plasma & $\cdots$ & $\begin{array}{l}0 \\
1 \\
0 \cdot 3 \\
0 \cdot 1\end{array}$ & $\begin{array}{r}10 \cdot 02 \\
9 \cdot 48 \\
10 \cdot 52 \\
10 \cdot 22\end{array}$ & $\begin{array}{l}0.54 \\
0.47 \\
0.51 \\
6.54\end{array}$ & $\begin{array}{l}12 \\
12 \\
12 \\
12\end{array}$ & $\begin{array}{l}100 \\
94 \cdot 6 \\
105 \\
102\end{array}$ \\
\hline Red cells & $\ldots$ & $\begin{array}{r}0 \\
10 \\
3 \\
1\end{array}$ & $\begin{array}{l}7.98 \\
1.87 \\
3.62 \\
6 \cdot 11\end{array}$ & $\begin{array}{l}0.27 \\
0.13 \\
0.46 \\
0.56\end{array}$ & $\begin{array}{l}6 \\
5 \\
6 \\
6\end{array}$ & $\begin{array}{c}100 \\
33 \\
45 \cdot 3 \\
76 \cdot 6\end{array}$ & Red cells & & $\begin{array}{l}0 \\
1 \\
0 \cdot 3 \\
0 \cdot 1\end{array}$ & $\begin{array}{l}7 \cdot 32 \\
4 \cdot 70 \\
6 \cdot 84 \\
6 \cdot 82\end{array}$ & $\begin{array}{l}0.35 \\
0.10 \\
0.32 \\
0.29\end{array}$ & $\begin{array}{l}12 \\
12 \\
12 \\
12\end{array}$ & $\begin{array}{c}100 \\
64 \cdot 2 \\
93 \cdot 4 \\
93 \cdot 1\end{array}$ \\
\hline
\end{tabular}

*Schradan was given at 10, 3, and 1 p.p.m. for 13 weeks in Experiment 2 and at 1, 0.3, and 0.1 p.p.m. for four weeks in Experiment 3.

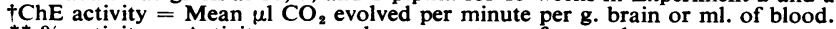

$* * \%$ activity $=$ Activity expressed as percentage of control group.

one lasted for 13 and the other for only four weeks. There is some depression of the activity of cholinesterase at 1 p.p.m. more marked in the red cells than in the plasma.

"Systox."-Two experiments with " systox" were done on female rats only and ran for 16 weeks. The rats on 50 p.p.m. were the only ones to show signs of poisoning which were typically those produced by a cholinergic drug, namely, widespread fasciculations, weakness, and tremors with evidence of excessive lachrymation and salivation. After four weeks three rats in this group were killed because of the severity of their illness but the rest gradually recovered in spite of continued ingestion of the diet. The growth curves are given in Fig. 4 and show that only those rats on 50 p.p.m. were affected.

There were no incidental deaths in these experiments, and no deaths from specific poisoning other than the three rats that were deliberately killed.

The daily food intake of the rats was measured throughout the experiments and the data for the rats on 50,20 , and 10 p.p.m. are given in Fig. 5. There are no differences between rats on 10 p.p.m. and the controls. At 20 p.p.m. growth was similar but food intake somewhat greater for several weeks. At 50 p.p.m. food intake was low for the first four weeks while the rats were obviously very ill but it then increased and remained very high for six weeks. The relationship between food intake and growth is shown in Fig. 6 where data for the controls and the 50 p.p.m. group are plotted. In spite of the high food intake the rats on 50 p.p.m. "systox" remained lighter than the control rats throughout the experiment (Table 5).

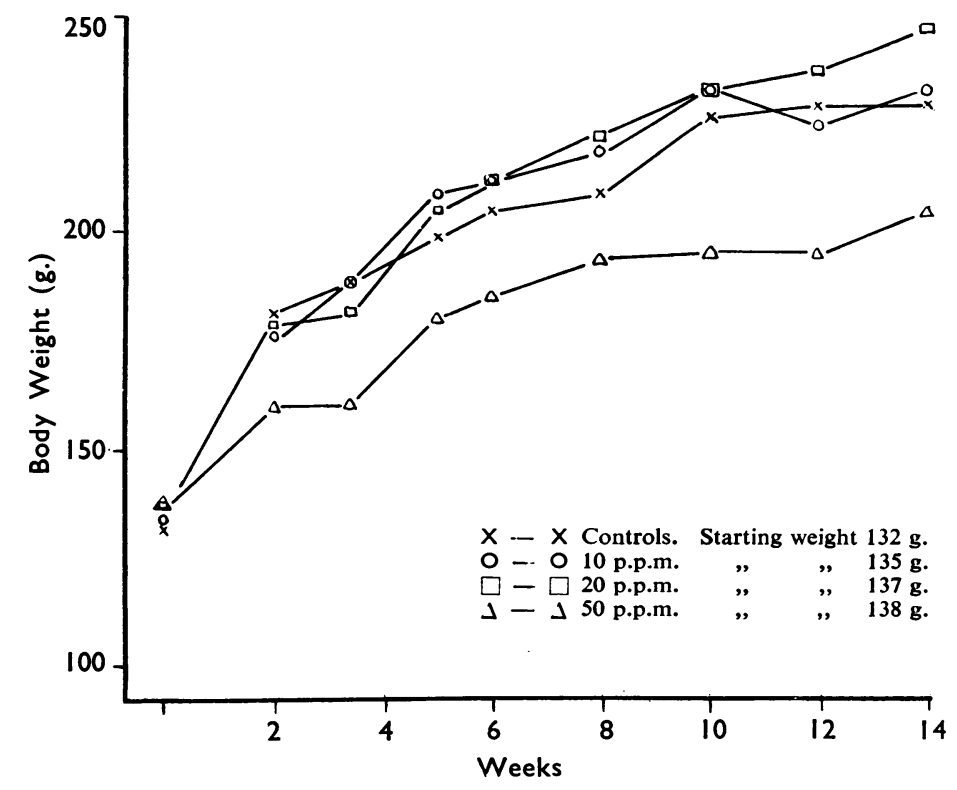

Fig. 4.-Weights of female rats on diets containing "systox" (Experiment 3). 


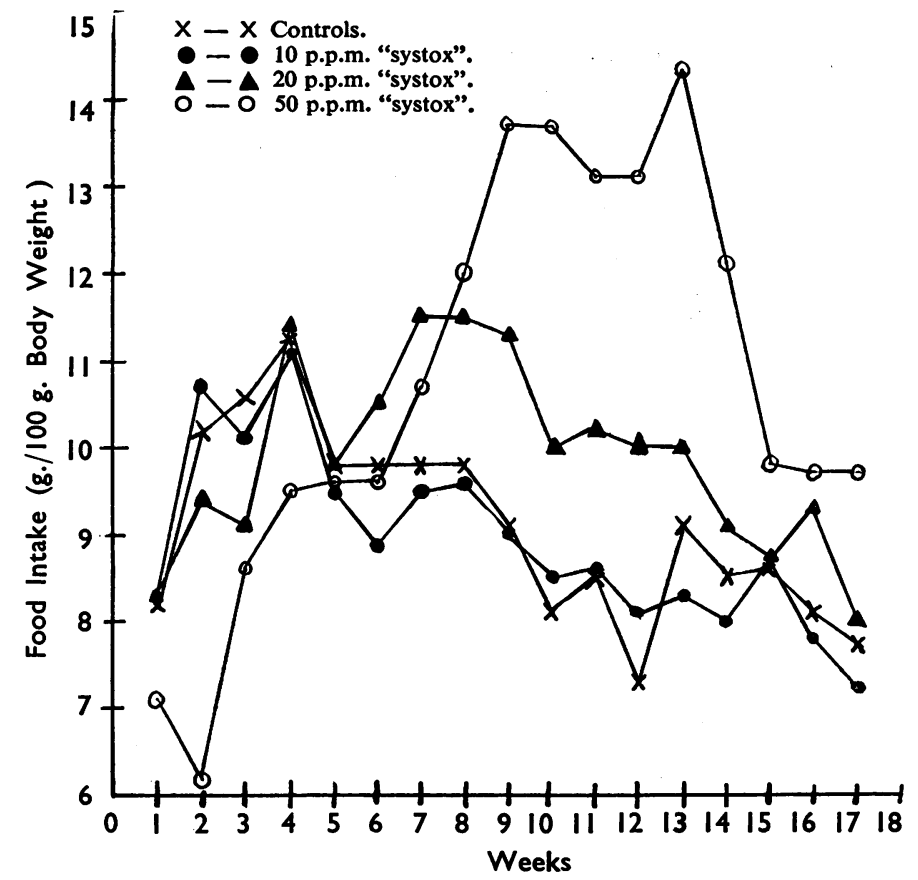

At 1 p.p.m. there is a detectable depression of both blood and brain cholinesterase. At 3 p.p.m. there is a reduction of the brain cholinesterase activity as great as that produced by 50 p.p.m. schradan (Table 3). At 20 p.p.m. there is a reduction of activity of over $80 \%$ of the brain cholinesterase in rats that were otherwise apparently normal. The rats on 50 p.p.m., because of their greater food intake, were consuming a dose of "systox" about three times greater than those on 20 p.p.m. but the inhibition of their brain cholinesterase only increased by another $6 \%$. Nevertheless at the time this experiment ended the rats on 50 p.p.m. with only $7 \%$ of their brain cholinesterase were not showing signs of poisoning.

FIG. 5.-The daily food intake of rats on diets containing " systox". Each point is the mean daily intake for a week expressed as g. of dry diet per $100 \mathrm{~g}$. body weight.

Although they started later and never reached the same final weight, the rate of growth of the rats on 50 p.p.m. "systox" was similar to that of the controls.

It was also surprising that the signs of poisoning diminished despite the increased intake of "systox" after the fourth week. The average daily intake of "systox" at different times during the experiment is given in Table 6 .

At the fourth week the rats on 50 p.p.m. were consuming $70 \%$ of a single lethal dose and at nine weeks the equivalent of a single lethal dose each day.

The values for blood and brain cholinesterase are given in Table 7.

(a) $\mathrm{X}-\mathrm{X}$ Food intake $\mathrm{g} . / 100 \mathrm{~g}$. body weight per day.

X ... X Mean body weight (g.)

(b)

- - Food intake

- ... Mean body weight.

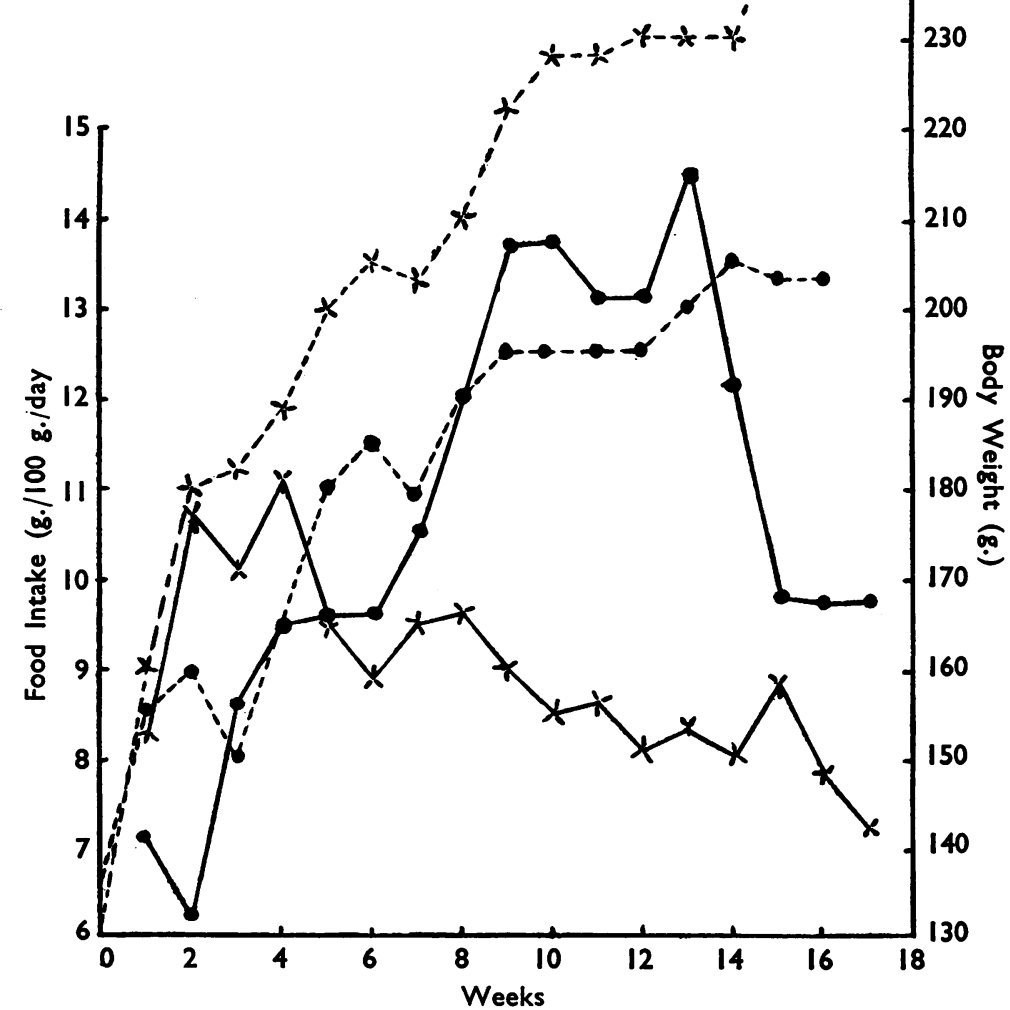

Fio. 6.-Comparison between the growth and food intake of $(a)$ normal rats $(b)$ rats on 50 p.p.m. "systox" in the diet. 
TABLE 5

MEAN WEIGHTS OF FEMALE RATS RECEIVING 50 P.P.M. "SYSTOX" COMPARED WITH CONTROL RATS AT DIFFERENT TIME IN EXPERIMENT 4

\begin{tabular}{c|c|c|c|c}
\hline & \multicolumn{4}{|c}{ Weight of Rats (g.) } \\
$\begin{array}{c}\text { Duration } \\
\text { of Experi- } \\
\text { ment } \\
\text { (weeks) }\end{array}$ & Control & $\begin{array}{c}50 \text { p.p.m. } \\
\text { Systox }\end{array}$ & t & p \\
\cline { 2 - 5 } & $\begin{array}{c}\text { Mean and } \\
\text { S.D. }\end{array}$ & $\begin{array}{c}\text { Mean and } \\
\text { S.D. }\end{array}$ & $\mathrm{s}$ & \\
\hline 2 & $180 \pm 15$ & $160 \pm 18$ & 4.08 & $<001$ \\
7 & $201 \pm 15$ & $181 \pm 11$ & 3.25 & $<0.01$ \\
12 & $230 \pm 18$ & $197 \pm 12$ & 4.52 & $<0.01$ \\
\hline
\end{tabular}

TABLE 6

DAILY INTAKE OF "SYSTOX" CALCULATED FROM AVERAGE DAILY FOOD INTAKE IN EXPERIMENT 4

\begin{tabular}{c|c|c|c}
\hline $\begin{array}{c}\text { Level in Diet } \\
\text { (p.p.m.) }\end{array}$ & \multicolumn{3}{|c}{ Average Daily Intake per Rat (mg./kg.) } \\
\hline 50 & 4th week & 9th week & 14th week \\
\hline 20 & 2.8 & $4 \cdot 1$ & 3.6 \\
\hline
\end{tabular}

Despite their lowered cholinesterase activity they were able to consume daily a dose of "systox" equivalent to $96 \%$ of a single lethal dose for a normal rat.

\section{Discussion}

The experiments with the higher doses of schradan and "systox" were designed along the conventional lines of tests for chronic toxicity. The usual criteria for such tests are non-specific such as death, failure to grow, or loss of weight, and changes in behaviour, i.e., signs of poisoning followed by a macroscopical and microscopical examination of the tissues of animals killed or dying during the experiments. A failure to grow normally and a few mild signs of poisoning were seen in the male but not in the female rats receiving 50 p.p.m. schradan. In those male rats receiving 10 p.p.m. there were no signs of poisoning. More severe signs of poisoning and a similar disturbance of growth were seen in the female rats on 50 p.p.m. "systox" but on 20 p.p.m. " systox" the rats behaved normally. No rats developed pathological changes in the tissues as a result of ingesting these insecticides at the highest levels used.

By the ordinary standards of a toxicity test $\mathbf{5 0}$ p.p.m. schradan and 20 p.p.m. " systox" were harmless to female rats. Both these compounds have at least one specific action, namely the power to inhibit cholinesterase after they have been ingested by the animal. Using this specific test it was found that both compounds were having an effect at dietary levels considerably below those producing other signs of intoxication. Thus, at 3 p.p.m. both produced a $30 \%$ inhibition of the blood cholinesterase activity and it is probable that a slight effect was produced even at 1 p.p.m. On the other hand, rats on 20 p.p.m. "systox" behaved apparently normally even though their brain cholinesterase activity had been $85 \%$ inhibited. If such a diet can be consumed without obvious signs of poisoning should a diet be considered "toxic" that will produce a depression of cholinesterase activity of 5 to $10 \%$ ?

TABLE 7

CHOLINESTERASE ACTIVITY OF BRAIN, WHOLE BLOOD, PLASMA, AND RED CELLS OF FEMALE RATS FED DIETS CONTAINING "SYSTOX"

\begin{tabular}{|c|c|c|c|c|c|c|c|c|c|c|c|c|}
\hline & \multicolumn{5}{|c|}{ Experiment $4^{*}$} & \multicolumn{7}{|c|}{ Experiment $5^{*}$} \\
\hline \multirow[b]{2}{*}{ Brain .. } & $\begin{array}{c}\text { Drug in } \\
\text { Diet } \\
\text { (p.p.m.) }\end{array}$ & $\underset{\text { Activity }}{+ \text { ChE }}$ & S.E. & $\begin{array}{l}\text { No. of } \\
\text { Rats }\end{array}$ & **A $\%$ & \multirow[b]{2}{*}{ Brain } & \multirow[b]{2}{*}{. } & $\begin{array}{c}\text { Drug in } \\
\text { Diet } \\
\text { (p.p.m.) }\end{array}$ & $\underset{\text { Activity }}{\text { ChE }}$ & S.E. & $\begin{array}{l}\text { No. of } \\
\text { Rats }\end{array}$ & $\begin{array}{c}\% \\
\text { Activity }\end{array}$ \\
\hline & $\begin{array}{r}0 \\
10 \\
20 \\
50\end{array}$ & $\begin{array}{c}175 \\
46 \\
22.95 \\
13.66\end{array}$ & $\begin{array}{l}7.56 \\
2.88 \\
3.81 \\
3.40\end{array}$ & $\begin{array}{l}12 \\
12 \\
12 \\
12\end{array}$ & $\begin{array}{c}100 \\
26.5 \\
13.1 \\
7.1\end{array}$ & & & $\begin{array}{r}0 \\
10 \\
3 \\
1\end{array}$ & $\begin{array}{r}209 \cdot 7 \\
42 \cdot 1 \\
138 \cdot 2 \\
194 \cdot 2\end{array}$ & $\begin{array}{r}10 \cdot 12 \\
1 \cdot 13 \\
4 \cdot 44 \\
6.90\end{array}$ & $\begin{array}{l}7 \\
8 \\
7 \\
7\end{array}$ & $\begin{array}{l}100 \\
20 \cdot 1 \\
66 \cdot 0 \\
93 \cdot 0\end{array}$ \\
\hline \multirow[t]{3}{*}{ Whole blood } & $\begin{array}{r}0 \\
10 \\
20 \\
50\end{array}$ & $\begin{array}{r}28 \cdot 87 \\
8 \cdot 21 \\
4 \cdot 25 \\
2 \cdot 40\end{array}$ & $\begin{array}{l}1.805 \\
0.69 \\
0.67 \\
0.83\end{array}$ & $\begin{array}{l}12 \\
12 \\
12 \\
12\end{array}$ & $\begin{array}{r}100 \\
28 \cdot 4 \\
14.8 \\
8.2\end{array}$ & \multicolumn{2}{|c|}{ Whole blood.. } & $\begin{array}{r}0 \\
10 \\
3 \\
1\end{array}$ & $\begin{array}{r}27.63 \\
5.89 \\
19.06 \\
24.92\end{array}$ & $\begin{array}{l}1.71 \\
0.42 \\
1.07 \\
1.29\end{array}$ & $\begin{array}{l}7 \\
8 \\
7 \\
7\end{array}$ & $\begin{array}{c}100 \\
21.2 \\
69.0 \\
90.0\end{array}$ \\
\hline & & & & & & Plasma & . & $\begin{array}{r}0 \\
10 \\
3 \\
1\end{array}$ & $\begin{array}{r}24 \cdot 49 \\
6 \cdot 57 \\
17.17 \\
23 \cdot 39\end{array}$ & $\begin{array}{l}2.65 \\
0.57 \\
1.61 \\
1.72\end{array}$ & $\begin{array}{l}7 \\
8 \\
7 \\
7\end{array}$ & $\begin{array}{c}100 \\
26 \cdot 8 \\
70 \cdot 0 \\
95 \cdot 5\end{array}$ \\
\hline & & & & & & $\begin{array}{c}\text { Red cells } \\
\text {. }\end{array}$ & . & $\begin{array}{r}0 \\
10 \\
3 \\
1\end{array}$ & $\begin{array}{l}7.50 \\
1.18 \\
5.96 \\
6.19\end{array}$ & $\begin{array}{l}0.70 \\
0.23 \\
0.85 \\
0.98\end{array}$ & $\begin{array}{l}7 \\
8 \\
7 \\
7\end{array}$ & $\begin{array}{l}100 \\
15 \cdot 8 \\
80 \\
83\end{array}$ \\
\hline
\end{tabular}

*In experiment 4, 50, 20, 10 p.p.m. "systox" was given for 16 weeks, and in Experiment 5, 10, 3, and 1 p.p.m. "systox" for 11 weeks. $+\mathrm{ChE}$ activity $=$ Mean $\mu \mathrm{l}$. $\mathrm{CO}_{2}$ evolved per minute per g. brain or ml. of blood.

$* * \%$ activity $=$ Activity expressed as percentage of control group. 
The two compounds exhibit some differences in their behaviour as inhibitors of cholinesterase in the rat. "Systox" always produces a greater degree of inhibition of the brain cholinesterase than schradan. Their effect upon the whole blood is similar but schradan consistently produces slightly more inhibition of the cholinesterase of the red cells than the cholinesterase of the plasma. It might seem reasonable to conclude that "systox" was more toxic than schradan at similar levels in the diet because it produced a greater effect upon the brain cholinesterase. Before reaching this conclusion it would be more satisfactory if we knew whether the inhibition of cholinesterase was the sole toxic action of these compounds and also more about the function of cholinesterase.

The rats on 50 p.p.m. "systox" were very ill for several weeks and then began to recover. By the end of the experiment signs of poisoning had disappeared but their brain and blood cholinesterase activity was only 7 to $8 \%$ of normal. The toxicity of an inhibitor of cholinesterase given in repeated doses will be determined to some extent by the rate at which inhibition of the cholinesterase is reversed. The mechanism of inhibition and its reversal have been studied in some detail (Aldridge, 1953b) and the rate of reversal of inhibition by organophosphorus compounds is determined by the nature of the alkoxy groups attached to the phosphorus (Aldridge and Davison, 1953). Unpublished observations in this laboratory by Davison have shown that with one inhibitor at least the speed with which the inhibition of cholinesterase is reversed in the rat is the same after a comparable degree of inhibition produced in one case by a single dose and maintained in the other continuously for six months by feeding. It seems unlikely that the tolerance developed by the rats to 50 p.p.m. "systox" was associated with any increase in the speed with which the inhibition of cholinesterase could be reversed. In any case, the extent to which this had taken place by the end of the experimental period was very small.

Observations of a different type have shown that adequate function of the myoneural junction of the rat may be maintained when only $10 \%$ of the normal activity of cholinesterase remains although disturbances in function may be produced while the inhibition is progressing (Barnes and Duff, 1953). It seems, therefore, more probable that the rats on 50 p.p.m. " systox" in some way adjusted themselves to an existence with only 7 to $8 \%$ of their normal quota of active cholinesterase.

Associated with this severe depression of cholinesterase activity there was a disturbance in growth and a defect in the body weight persisting throughout the experiment. But for the last eight weeks this defect in growth was associated with an abnormally large food intake (Fig. 5). This demand for more food may be part of the adjustment of the animal to serious defects in its tissue cholinesterase levels. If this is so, it implies that cholinesterase has functions not yet recognized. The increased intake of food might be for quite different reasons and perhaps related to poor utilization of the food ingested. There might be an increased mobility of the gut due to overaction of acetylcholine causing a too rapid passage of food. Digestion might be disturbed by the action of "systox" on other enzymes in the gut. Esterases other than cholinesterases (Aldridge, 1953a) as well as chymotrypsin (Hartley and Kilby, 1952) are very sensitive to these organo-phosphorus compounds. An answer to this question might well throw more light on the action of "systox" and related anti-cholinesterases.

The defect in growth of the male rats on 50 p.p.m. schradan was not associated with a reduction of the tissue cholinesterase activity as marked as that of the rats (female) on 20 p.p.m. "systox" which grew normally. Female rats of 50 p.p.m. schradan had a similar degree of inhibition to that produced in the males but they grew normally. The growth of male rats may be more sensitive than that of females to a depression of cholinesterase activity or schradan may interfere with growth by another mechanism. The failure of male rats on schradan to grow properly was not associated with any alteration in the food intake. In the rat schradan is converted into an inhibitor of cholinesterase in the liver. Neither male nor female rats show any histological changes in the liver as a result of this, but it is conceivable that this process of chemical transformation of schradan might interfere with a factor more important to the growth of male than of female rats.

It is difficult to use these experiments to make a comparison between the toxicity of "systox" and schradan. For female rats "systox" is more poisonous than schradan at a level of 50 p.p.m. and at lower levels it produces more inhibition of the brain cholinesterase than does schradan. Little is known of the factors that determine the degree of inhibition produced in different tissues by different inhibitors of this group. Nor is it known what part selectivity in the site of action plays in determining the toxicity of a given inhibitor of cholinesterase. While the importance of cholinesterase in the nervous system would appear to be outstanding less is known about the function of this enzyme at other sites including, for example, the red blood cells. The action of schradan on the growth of male rats 
suggests an action of this compound possibly unrelated to that on cholinesterase and this might be of equal or greater importance if more was known about it.

The significance of a small (10\%) depression of cholinesterase activity remains unknown. So little is known about the specific actions of other toxic substances in the whole animal that it is not possible to say at present whether it is usual for signs of intoxication to appear only when $90 \%$ of some enzyme activity has been inhibited or whether it is more usual for such signs to appear after smaller depressions of some specific activity.

The value of toxicity tests and their interpretation will be improved only when more information along such lines has been acquired.

\section{Summary}

Rats have been given diets containing 50, 10, $3,1,0.3$, and 0.1 p.p.m. schradan (octamethyl pyrophosphoramide) and 50, 20,10,3, and 1 p.p.m. "systox" (OO-diethyl-S-ethyl thioethanol thiophosphate).

Signs of poisoning and diminished growth were found in male but not female rats at 50 p.p.m. schradan. "Systox" was given only to female rats and those receiving 50 p.p.m. showed signs of poisoning and did not grow as well as the controls.

Rats on 20 p.p.m. "systox" appeared normal although the activity of the cholinesterase of their blood and brain was only about $15 \%$ of normal.

"Systox" affected the blood and brain cholinesterase equally and had a similar activity toward the true and pseudo-cholinesterase of the rat. Schradan affected the blood more than the brain and preferentially attacked true rather than pseudocholinesterase.

Signs of poisoning in animals receiving 50 p.p.m. " systox" became very severe after three to four weeks but gradually decreased despite continued feeding. An initially low food intake became much greater than that of the control rats for the later part of the experiment. Blood and brain cholinesterase activities were inhibited to $95 \%$ of normal.

Schradan at 50 p.p.m. had a less serious effect on the cholinesterase even in the rats where growth was depressed. The food intake of these rats was normal.

Some inhibition was seen in rats fed 3 p.p.m. of either "systox" or schradan and a slight effect was recorded even at 1 p.p.m.

No histological changes were observed in the rats on the highest doses of schradan or "systox".

The findings are discussed and reference made to the difficulties of interpreting tests for chronic toxicity.

We wish to thank Mr. C. G. Taylor of the Agriculture Research Council for obtaining the sample of "systox", Dr. Bellamy of the Chemical Inspectorate, Ministry of Supply, Woolwich, for the analyses of the sample, and Mr. B. Topley of Albright \& Wilson Ltd., for the supply of schradan.

Mr. C. R. Kennedy was responsible for the running and the records of the feeding experiments and Mrs. Kemp and Mr. A. Batchelor for the cholinesterase determinations.

\section{REFERENCES}

Aldridge, W. N. (1950). Biochem. J., 46, 451. - (1953a). Ibid., 53, 110

- - (1953b). Ibid., 54, 442.

, and Davison, A. N. (1953). Ibid. In the press. Barnes, J. M., and Denz, F. A. (1951). J. Hyg. Lond., 49, 430 C, and Duff, J. I. (1953). Brit. J. Pharmacol., 8, 334. Cheng, K. K. (1951). Brit. J. exp. Path., 32, 444.

DuBois, K. P., Doull, J., and Coon, J. M. (1950). J. Pharmacol.,

9rawley, J. P., Hagen, E. C., and Fitzhugh, O. G. (1952). Ibid., 105, 156.

Gardiner, K., and Heath, D. F. (1953). Analyt. Chem. In the press. Hartley, B. S., and Kilby, B. A. (1952). Biochem. J., 50, 672.

Levine, M. G., and Suran, A. A. (1951). Enzymologia, Amst., 15, 17. Nevine, M. G., and Suran, A. A. (19. M. A. (1945). J. biol. Chem., Nachmansohn,

Rider, J. A., Eilinwood, L. E., and Coon, J. M. (1952). Proc. Soc. exp. Biol. N.Y., 81, 455 .

Wirth, W. (1953). Arch. exp. Path. Pharmak., 217, 144. 